DOI: 10.17707/AgricultForest.64.3.13

\begin{abstract}
Matheus Vinicius de Abadia VENTURA, Jadson Belem de MOURA, Rodrigo Fernandes de SOUZA, Wagner Gonçalves VIEIRA JUNIOR, Elivan Cesar Vieira ROCHA, Júlio Cesar SILVA ${ }^{1}$
\end{abstract}

\title{
INFLUENCE OF ARBUSCULAR MYCORRHIZAL FUNGI IN THE ESTABLISHMENT OF PRE-BROKEN SUGAR CANE
}

\begin{abstract}
SUMMARY
The objective of this work was to evaluate the influence of arbuscular mycorrhizal fungi on the initial development of pre-sprouted seedlings in three sugarcane varieties (CTC 9004 M, IACSP 955094 and IACSP 962042). The experiment was conducted in a greenhouse in the experimental field and in the agricultural microbiology laboratory of the Goianesia Evangelical Faculty located in the city of Goianésia, Goiás. The experimental design was a 3x2 factorial scheme with 5 replications in which the first factor was constituted by three varieties of sugarcane and the second factor by treatments: sterile soil with inoculation of arbuscular mycorrhizal fungi (AMF) and sterile soil without inoculation. AMF were inoculated directly into the roots of the seedlings. For the determination of growth and development were made count of number of tiller, stem diameter, dry mass of roots, shoot height, mycorrhizal colonization, spore density and identification of associated genera. The data received statistical treatment through the Assistat program. There was statistical difference only in the variety factor, in the variables plant height, spore density and mycorrhizal colonization rate. The genera Claroideglomus, Diversipora and Glomus were identified in all three varieties.
\end{abstract}

Key words: FMA, Saccharum spp., mycorrhiza.

\section{INTRODUCTION}

Brazil is today the largest producer of sugarcane, which makes the country the world leader in raw material production and ethanol production (UNICA, 2017). The Agronomic Institute of Campinas (IAC) launched in 2009 a technique that intends to change the concept of sugarcane plantation in Brazil. The system of pre-budded seedlings (PBS) of cane, as it is known, foresees the rapid production of seedlings, associated with high planting pattern, vigor and uniformity of planting (Landell et al., 2013).

Unlike the conventional system that uses whole stems for planting, the PBS takes to the field only the pre-budded seedlings originated from the cutting

\footnotetext{
${ }^{1}$ Matheus Vinicius de Abadia Ventura, Jadson Belem de Moura (corresponding author: jadsonbelem@gmail.com), Rodrigo Fernandes de Souza, Wagner Gonçalves Vieira Junior, Elivan Cesar Vieira Rocha, Júlio Cesar Silva, Faculdade Evangélica de Goianéisa, Dpto. SEDMO - Soils, Ecology and Dynamics of Organic Matter, Avenida Brasil, 1000. Goianésia, Goias, BRAZIL

Notes: The authors declare that they have no conflicts of interest. Authorship Form signed online.
} 
of the stem, known as wheels, which have an average of $3 \mathrm{~cm}$ in length, where the buds are located. The technology has already been adopted by small producers and associations of Goias and Central region of Sao Paulo (Souza \& Junior, 2013). However, it takes approximately 60 days for the entire process to be completed and the seedlings are perfectly rooted and ready for planting in the field.

The PBS system that uses individualized sugarcane grinding wheels is a rapid multiplication technology that allows the reduction of the volume of vegetal material used in the planting, better control of vigor and high phytosanitary standard, promote sugarcane of excellent clonal standard. The fact of substantially reducing the volume of plant material needed for planting automatically results in a higher gain for the mills, since this material can be used for its production of alcohol or sugar, which will depend on the company's objective (Landell et al., 2013; Xavier et al., 2014).

Unlike traditional planting, seeding pre-sprouted seedlings can be done with adapted machinery which has made the process faster. It is estimated that there is a reduction of 18 to 20 tons (t) of plant material per hectare when the planting is performed with the PBS system, which represents considerable financial gain in the sugar and alcohol industry (Souza \& Junior, 2013). Although it is a simple technique, studies on this technique are still lacking, especially those related to the use of plant growth promoting microorganisms, which can be easily applied in encapsulated gems, as predicted in this work. Therefore, the present proposal may contribute significantly to the understanding of the sprouting process and establishment of the seedling in assessing the influence of arbuscular mycorrhizal fungi without its establishment.

According Landell et al. (2012) with the advent of mechanical planting, the faults became more frequent and, in order not to result in significant losses in productivity, the volume of seedlings used became very high, being used up to more than $20 \mathrm{t} / \mathrm{ha}$. If a tonne of sugarcane contains 8,000 to 20,000 yolks, it is concluded that the number of yolks per meter is between 24 and 60 yolks, which is therefore an overspending of stalks that could be destined to industry.

Mycorrhizal fungi perform a mutualistic symbiotic association with most cultivated and native plants, benefit the development of the plant due to the greater absorption of water and nutrients, especially phosphorus that has low mobility in the soil (George et al., 1995; Elbon \& Whalen, 2014). These microorganisms occupy an important ecological niche in the ecosystems and bring benefits to the associated plant that can increase the rate of seedlings establishments in field conditions (Mohan et al., 2014; Soka \& Ritchie, 2015).

When it comes to mycorrhization in sugar cane, it can be noticed the shortage of work, this happens because the culture presents a long and large cycle, which makes it difficult to evaluate it in controlled environments, there are no conclusive results about this mycorrhizal interaction (Reis et al., 1999; Silveira \& Freitas, 2007). 
This work aimed to evaluate the influence of arbuscular mycorrhizal fungi on the early development of pre-sprouted seedlings in three varieties of sugarcane.

\section{MATERIAL AND METHODS}

The experimental design was the $3 \times 2$ factorial scheme with five replications, the first factor was constituted by three sugarcane varieties (CTC 9004M, IAC SP 95-5094 and IAC SP 96-2042) and the second factor by treatments: soil sterile with spore inoculation of mycorrhizal fungi and sterile soil without inoculation of spores. The experiment was carried out in the greenhouse and agricultural microbiology laboratory of the Evangelical Faculty of Goianesia.

The sugarcane varieties (Saccharum officinarum L.) were chosen according to regional utilization. The buds were from the Jalles Machado mill and were planted in polystyrene trays with commercial Bioplant ${ }^{\circledR}$ substrate and kept in a greenhouse for 30 days.

After 30 days of growth the seedlings were transplanted into $290 \mathrm{~cm} 3$ tubes with Bioplant ${ }^{\circledR}$. Then the seedlings were grown in a greenhouse. After this, they were transferred to 5-liter pots with sterile soil according to the proposed design and with formulated NPK fertilizer (04-30-10). It was conducted inside the greenhouse and irrigation occurred due to the need of the plant.

The spores of arbuscular mycorrhizal fungi (AMF) were extracted from $500 \mathrm{~cm} 3$ soil of native cerrado area with characteristics of ciliary forest closed by the wet sieving technique (Gerdemann \& Nicolson, 1963), followed by centrifugation in water and 50\% sucrose solution. The spores were separated according to their phenotypic characteristics as color, size and shape, composing the different morphotypes under stereoscopic binocular loupe.

For the determination of growth and development the following biometric analyzes were made of plant height, stalk diameter, root dry mass weight, number of tillers, mycorrhizal colonization rate, spore density and identification of associated genera.

In order to determine the percentage of colonization, the roots were clarified and stained with $0.05 \%$ Trypan Blue in lactoglycerol (Phillips \& Hayman, 1970) and the evaluation of the colonization was made under a stereoscopic microscope, following the technique of intersection of the quadrants (Giovannetti \& Mosse, 1980).

For the identification of the AMF genera from the morphological characteristics, the spores were separated according to their morphotypes and assembled on slides with pure polyvinyl lactoglycerol (PVLG) and PVLG mixed with Melzer $(1: 1 \mathrm{v} / \mathrm{v})$. To support the work of identification, we used original articles of the species description and descriptions of species provided on the website of the "International Culture Collection of Arbuscular and VesicularArbuscular Mycorrhizal Fungi” (Invam, 2018). 


\section{RESULTS AND DISCUSSION}

The $\mathrm{F}$ test shows the significance of the differences of means, in which statistical differences were verified only in the variety factor, in the variables plant height, spore density and mycorrhizal colonization rate (Table 1). No statistical difference was observed between the varieties in relation to root dry weight, stalk diameter and number of tillers. There was no statistical difference regarding inoculation.

Table 1. F test of sugarcane varieties without and with inoculation of arbuscular mycorrhizal fungi

\begin{tabular}{|l|c|c|c|c|c|c|}
\hline $\begin{array}{c}\text { Source of } \\
\text { Variation }\end{array}$ & $\begin{array}{c}\text { Root } \\
\text { Dough }\end{array}$ & Height & Diameter & Thorns & $\begin{array}{c}\text { Density of } \\
\text { Spores }\end{array}$ & $\begin{array}{c}\text { Mycorrhizal } \\
\text { Colonization }\end{array}$ \\
\hline Variety & $0,7811 \mathrm{~ns}$ & $4.3168 *$ & $1.5444 \mathrm{~ns}$ & $1.7528 \mathrm{~ns}$ & $9.5967 * *$ & $5.6986 * *$ \\
\hline Inoculation & $0,0117 \mathrm{~ns}$ & $1.2756 \mathrm{~ns}$ & $1.2000 \mathrm{~ns}$ & $0.5506 \mathrm{~ns}$ & $0.6928 \mathrm{~ns}$ & $0.4139 \mathrm{~ns}$ \\
\hline Var. x Inoc. & $0,5037 \mathrm{~ns}$ & $0.3289 \mathrm{~ns}$ & $0.4111 \mathrm{~ns}$ & $0.7191 \mathrm{~ns}$ & $1.4135 \mathrm{~ns}$ & $1.4175 \mathrm{~ns}$ \\
\hline
\end{tabular}

* significant at the $5 \%$ probability level $(.01=<\mathrm{p}<.05)$; ns - not significant ( $>=.05)$

Tristão et al. (2016), when evaluating initial parameters of sugarcane under influence of mycorrhizal fungi, did not observe statistical differences in stem diameter values. In the same study, the authors found a positive influence of the AMF on the variety IAC 91-1099 on the variables of root dry mass and number of tillers.

Andreola et al. (1985) evaluated the influence of six species of arbuscular mycorrhizal fungi on the growth and development of three varieties of sugarcane, they found benefits in the development of the varieties, and showed that their efficiency differs according to fungus and variety. Studies have shown that mycorrhizal fungi increase the uptake of nutrients, especially nutrients with low soil mobility, such as phosphorus, copper and zinc, so it is more appropriate to choose varieties that are more efficient in the use of nutrients and which have easier interactions with mycorrhizal fungi arbuscular (Tellechea, 2007). Silva et al. (2016) did not verify differences in the diameter of the colon in embaúba seedlings under the inoculation of arbuscular mycorrhizal fungi.

There was difference in relation to plant heights of the three varieties, and the variety IAC SP 96-2042 was statically inferior to the varieties IAC SP 955094 and CTC 9004M (Figure 1).

Tristão et al. (2016), when evaluating plant height under the influence of mycorrhizal fungi, verified differences among the varieties, and demonstrated that mycorrhizal fungi can develop symbiosis with some varieties more easily than with others. The authors verified higher average values in the varieties IAC SP 95-5094 and IAC 91-1099 and lower average values in IAC SP 97-4039 and IAC SP 95-5000. It is possible to observe that the variety IAC SP 95-5094 has an ease of interaction with arbuscular mycorrhizal fungi. The height of the plant is a 
very determinant index for the growth and development in the sugar cane, because it is a factor that will determine the final productivity.

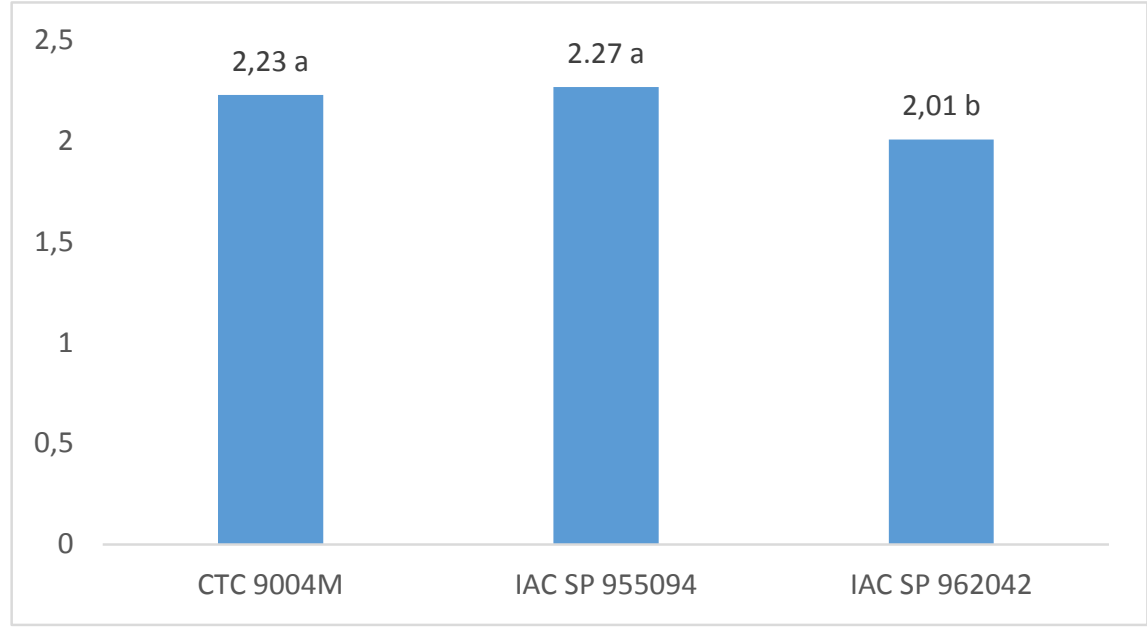

Figure 1. Plant height of three varieties of sugarcane.

$$
\mathrm{CV}=9.67 \%
$$

The symbiosis between mycorrhizal seedlings and fungi has positive effects such as increases in $\mathrm{CO}$ assimilation rates, transpiration rates and a higher rate of stomatal opening, as well as a higher vegetative growth rate (Schwob et al., 1998; Diniz, 2007; Oliveira et al., 2015).

There was a difference in spore density in samples of sugarcane varieties, being the CTC $9004 \mathrm{M}$ variety statically inferior to the varieties IAC SP 95-5094 and IAC SP 96-2042 (Figure 2).

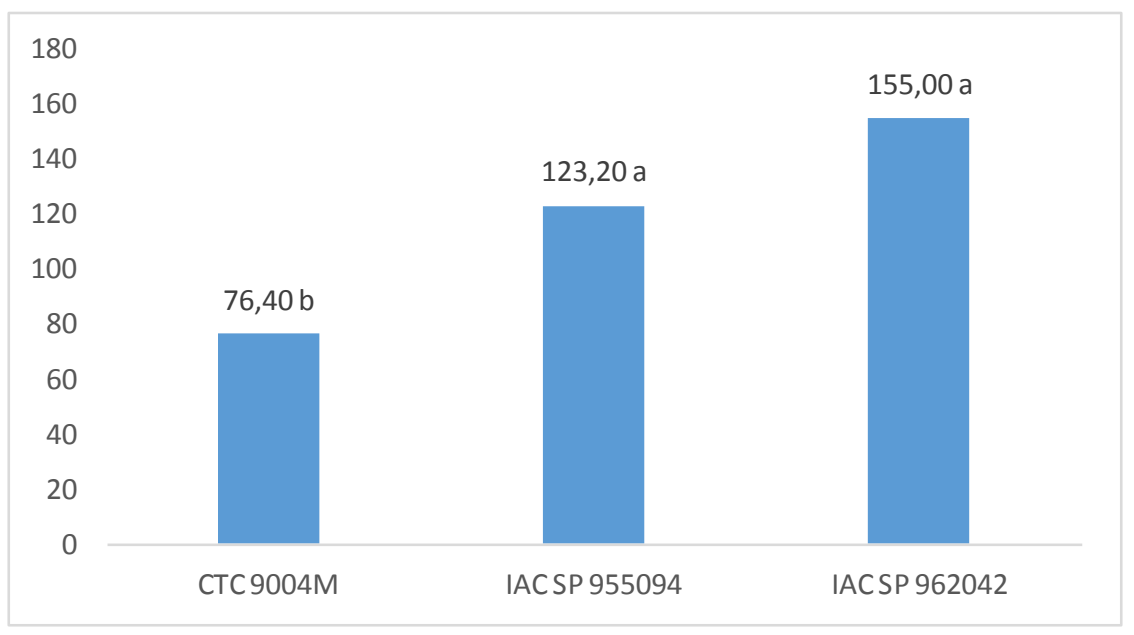

Figure 2. Density of spores in three varieties of sugarcane.

$$
\mathrm{CV}=34.15 \%
$$


The papers of Ambrosano et al. (2011) and Moura et al. (2016) presented that there was no significant difference in spore density in the sugar cane crop.

In relation to the rate of mycorrhizal colonization in samples of sugarcane varieties, a significant difference was observed between the averages, in which the CTC 9004M variety was statically inferior to the varieties IAC SP 95-5094 and IAC SP 96-2042 (Figure 3).

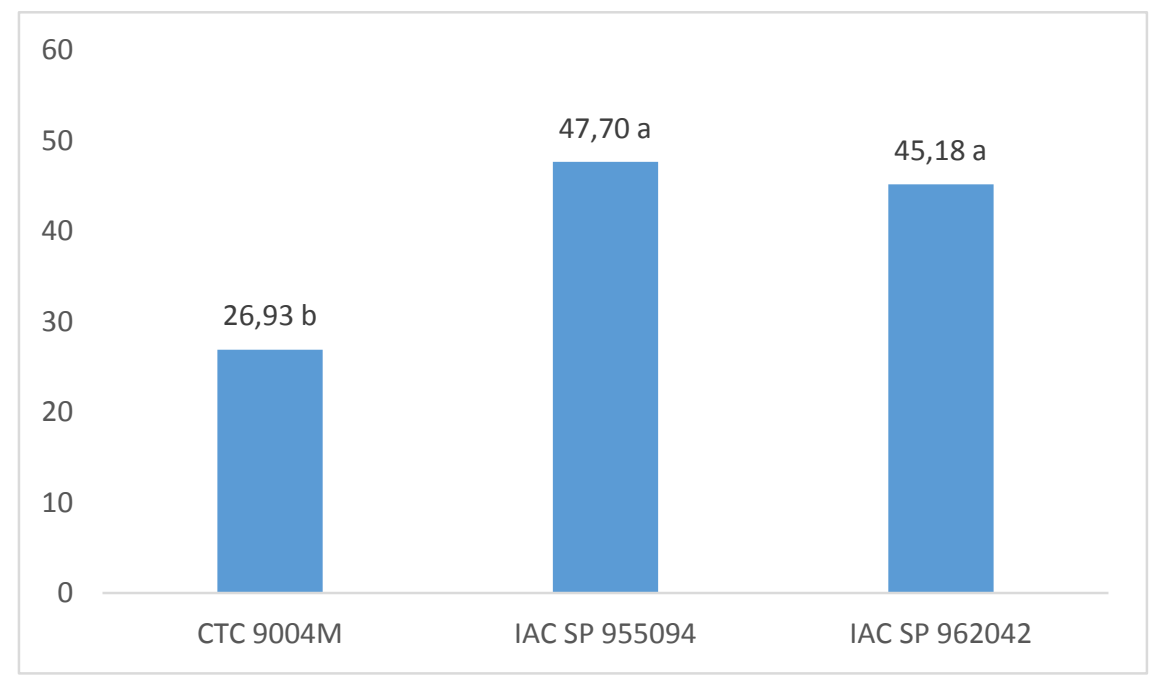

Figure 3. Mycorrhizal colonization rate in three varieties of sugarcane.

$$
\mathrm{CV}=31.11 \%
$$

Authors report that fungi have an easier mycorrhizal interaction and more sporulation in certain crops and the particular varieties or cultivars, in relation to others. In the work of Silva et al. (2016), the number of AMF spores was significant in embaúba seedlings, the same result regarding sporulation was found in the acerola crop when inoculated with mycorrhizal fungi (Balota et al., 2011) and papaya culture (Machineski et al., 2011). Significant values were found in the myriad culture belonging to the family Ericaceae with the cultivars Georgia, Misty and O'neal and lower values in the cultivars of Delite and Climax (Lima, 2014), this reinforces that fungi perform mycorrhizal interaction more easily in some crops and in certain varieties.

In the analyzed samples the genera that interacted with sugarcane varieties were identified, among them the genres: Acaulospora, Claroideglomus, Diversispora, Gigaspora and Glomus (Table 2).

Three of these genera were identified and observed according to Tellechea (2007), the species that are most predominant to interact with sugarcane are of the genres: Acaulospora, Scutelospora, Glomus e Gigaspora. In the work of Miranda (2008) higher rates were identified in the genus Glomus, which is one of the most common genus in the Cerrado. 
Table 2. Genus of arbuscular mycorrhizal fungi found associated with the rhizosphere of three sugarcane varieties without and with inoculation of arbuscular mycorrhizal fungi

\begin{tabular}{lcccccc}
\hline & \multicolumn{3}{c}{ Inoculated varieties } & \multicolumn{3}{c}{ Uninoculated varieties } \\
\cline { 2 - 7 } \multicolumn{1}{c}{ Genres } & CTC & IAC SP & IAC SP & CTC & IAC SP & IAC SP \\
& $9004 \mathrm{M}$ & 955094 & 962042 & $9004 \mathrm{M}$ & 955094 & 962042 \\
\hline Acaulospora & - & + & + & - & + & + \\
Claroideglomus & + & + & + & - & + & + \\
Diversispora & + & + & + & + & + & + \\
Glomus & + & + & + & + & + & + \\
Gigaspora & - & - & + & - & - & - \\
\hline
\end{tabular}

According Fernandes et al. (2010), the genus Glomus was the genus for which a greater number of spores were observed under the pigeon pea, in carrots and beans, Glomus and Gigaspora were the largest numbers of spores, also.

\section{CONCLUSIONS}

The use of arbuscular mycorrhizal fungi in the sprout phase of sugarcane promoted higher results at the height of the varieties in IAC SP 955094 and CTC $9004 \mathrm{M}$ in relation to the variety IAC SP 962042.

Mycorrhizal colonization and spore density showed significant values in the varieties IAC SP 955094 and IAC SP 962042.

The genres Claroideglomus, Diversispora and Glomus were identified in all three varieties. The variety IAC SP 962042 presented five genera of mycorrhizal fungi.

\section{REFERENCES}

Ambrosano, E. J.; Cantarella, H.; Ambrosano, G. M. B.; Schammas, E. A.; Dias, F. L. F.; Rossi, F.; Trivelin, P. C. O.; Muraoka, T.; Sachs, R. C. C.; Azcón, R. 2011. Produtividade Da Cana-De-Açúcar Após O Cultivo De Leguminosas. Bragantia, V. 70, N. 4, P. 810-818.

Andreola, F., Cardoso, E. J. B. N., Silveira, A. P. D. 1985. Efeito De Seis Espécies De Fungos Micorrízicos Vesiculo Arbusculares Sobre O Desenvolvimento De Três Variedades De Cana-De-Açúcar. Tecnologia/Pesquisa Stab. P. 35- 89.

Balota, E. L.; Machineski, O.; Stenzel, N. M. C. 2011. Resposta Da Acerola À Inoculação De Fungos Micorrízicos Arbusculares Em Solo Com Diferentes Níveis De Fósforo. Bragantia, V. 70, N. 1, P. 166-175.

Diniz, P. F. A. 2007.Influência Do Fungo Micorrízico Arbuscular (Glomus Clarum) Sobre Características Biofísicas, Nutricionais, Metabólicas E Anatômicas Em Plantas Jovens De Seringueira. 125 P. Dissertação (Mestrado Em Agronomia) Universidade Federal De Lavras, Lavras.

Elbon, A.; Whalen, J. K. 2014. Phosphorus Supply To Vegetable Crops From Arbuscular Mycorrhizal Fungi: A Review. Biological Agriculture \& Horticulture, N. AheadOf-Print, P. 1-18.

Fernandes, S. G., Machado, C. T. T., Lopes, V., Vilela, M. F., \& Fernandes, L. A. 2010. Fungos Micorrízicos Arbusculares Em Áreas De Agricultores Familiares Da Comunidade Água Boa 2, Rio Pardo De Minas, Mg. Embrapa Cerrados, 28 P. 
George, E.; Marschner, H.; Jakobsen, I. 1995. Role Of Arbuscular Mycorrhizal Fungi In Uptake Of Phosphorus And Nitrogen From Soil. Critical Reviews In Biotechnology, V. 15, N. 3-4, P. 257-270

Gerdemann, J.; Nicolson, T. H. 1963. Spores Of Mycorrhizal Endogone Species Extracted From Soil By Wet Sieving And Decanting. Transactions Of The British Mycological Society, V. 46, N. 2, P. 235-244.

Giovannetti, M.; Mosse, B. 1980. An Evaluation Of Techniques For Measuring Vesicular Arbuscular Mycorrhizal Infection In Roots. New Phytologist, V. 84, N. 3, P. 489500.

Ibge. Censos Agropecuários. 2010. Disponível Em: <Www.Ibge.Com.Br> Acessed in: 20 of november of 2016.

Invam. International Culture Collection of Arbuscular Mycorrhizal Fungi 2018. Disponible in: http://Invam.Caf.Wvu.Edu/Fungi/Taxonomy/Classification

Landell, M. G. De A.; 2012. Campana, M. P.; Figueiredo, P. Sistema De Multiplicação De Cana-De-Açúcar Com Uso De Mudas Pré-Brotadas (Mpb), Oriundas De Gemas Individualizadas, Campinas: Instituto Agronômico, 16 P.

Landell, M. G. D. A., Scarpari, M. S., Xavier, M. A., Anjos, I. A. D., Baptista, A. S., Aguiar, C. L. D., \& Campos, M. F. D. 2013. Residual Biomass Potential Of Commercial And Pre-Commercial Sugarcane Cultivars. Scientia Agricola, V. 70, N. 5, P. 299-304.

Lima, P. E. 2014. Propágulos De Fungos Micorrízicos Arbusculares Na Rizosfera E Potencial De Utilização No Enraizamento De Estacas De Mirtileiro (Vaccinium Spp). Universidade Federal De Itajubá, 44 P.

Machineski, O.; Balota, E. L; Souza, J. R. P. De. 2011. Resposta Da Mamoneira A Fungos Micorrízicos Arbusculares E A Níveis De Fósforo. Semina: Ciências Agrárias, V. 32, P. 1855-1862.

Miranda, J. C. C. De. 2008. Micorriza Arbuscular: Ocorrência E Manejo. Planaltina, Df: Embrapa Cerrados, 169 P.

Mohan, J. E.; Cowden, C. C.; Baas, P.; Dawadi, A.; Frankson, P. T.; Helmick, K.; Hughes, E.; Khan, S.; Lang, A.; Machmuller, M. 2014. Mycorrhizal Fungi Mediation Of Terrestrial Ecosystem Responses To Global Change: Mini-Review. Fungal Ecology, V. 10, P. 3-19.

Moura, J. B. Diversidade E Colonização Micorrízica Em Diferentes Usos Do Solo No Cerrado. 2015. Brasília: Faculdade De Agronomia E Medicina Veterinária, Universidade De Brasília, 124p.

Oliveira, J. J. F.; Alixandre, T. F.; Miranda, J. M. S. 2015. Mudas De Castanha-DoGurguéia Micorrizadas Sob Níveis De Esterco De Caprinos. Pesquisa Florestal Brasileira, V. 35, N. 83, P. 189-197.

Ortas, I.; Ustuner, O. 2014. Determination Of Different Growth Media And Various Mycorrhizaespecies On Citrus Growth And Nutrient Uptake. Scientia Horticulturae. P. 84-90.

Phillips, J.; Hayman, D. 1970. Improved Procedures For Clearing Roots And Staining Parasitic And Vesicular-Arbuscular Mycorrhizal Fungi For Rapid Assessment Of Infection. Transactions Of The British Mycological Society, V. 55, N. 1, P. 158161.

Reis, V.M.; Paula, M.A.; Döbereiner, J. 1999. Ocorrência De Micorrizas Arbusculares E Da Bactéria Diazotrófica Acetobacter Diazotroficus Em Cana-De-Açúcar. Pesquisa Agropecuária Brasileira, V.34, P.1933-1941.

Schwob, I.; Ducher, M.; Sallanon, H.; Coudret, A. 1998. Growth And Gas Exchange Responses Of Hevea Brasiliensis Seedlings To Inoculation With Glomus Mosseae. Trees, V. 12, P. 236-240. 
Silva, E. P.; Gomes, V. F.; Furtado, P. M. F.; Júnior, M. T. S., \& Ness, R. L. 2016. Desenvolvimento E Colonização Micorrízica Em Mudas De Embaúba Adubadas Com Fosfato Natural E Material Orgânico. Revista Ciência Agronômica, V. 47, N. 2, P. 256.

Silveira, A. P. D. \& Freitas, S. S. 2007. Microbiota Do Solo E Qualidade Ambiental. Campinas, Instituto Agronômico, 317p.

Soka, G.; Ritchie, M. 2015. Arbuscular Mycorrhizal Symbiosis, Ecosystem Processes And Environmental Changes In Tropical Soils. Applied Ecology And Environmental Research, V. 13, N. 1, P. 229-245.

Souza, A. G., \& Junior, J. C. 2013. Expansão Da Cana-De-Açúcar No Triângulo Mineiro E Os Efeitos Sobre A Agricultura Familiar E O Trabalho Rural. Revista Tópos, V.3, N.2, P. 8-35.

Tellechea, F. R. F. 2007. Fungos Micorrízicos, Bactérias Diazotroficas Endolíticas E Fósforo No Crescimento E Acumulo De Nutrientes Em Mudas De Cana De Açúcar. Universidade Estadual Do Norte Fluminense Darcy Ribeiro. 64 P.

Tristão, L. E.; Figueiredo, P. A. M.; Zied, D. C.; Lisboa, L. A. M.; Alves, V. G. Da C. 2016. Initial Agronomic Parameters Of Sugarcane Inoculated With Mycorrhizal Mycorrhizal Fungi. $1^{\circ}$ Encontro Internacional De Ciências Agrárias E Tecnológicas - Crise: Tecnologias Para A Superação De Desafios No Setor Agrário, Universidade Estadual De São Paulo. 9 P.

Unica. União Da Agroindústria Canavieira De São Paulo. 2017. Cana-De-Açúcar: Produtos. < Http://Www.Unicadata.Com.Br/Listagem.Php?Idmn=73.> Acesso Em Julho De 2017, 7 P.

Xavier, M. A., Perecin, D., Alvim, K. R. T., Landell, M. G. A., \& Arantes, F. C. Seleção 2014. De Famílias E Progênies De Irmãos Completos De Cana-De-Açúcar Para Atributos Tecnológicos E De Produção Pelo Método De Reml/Blup. Bragantia, V. 73 N. 3, P. 253-262. 